Jane W. Loeb

\title{
The Status of Female Faculty in the U.S.: Thirty-five Years with Equal Opportunity Legislation
}

Abstract missing

Keywords missing

Correspondence address missing

Key words: Resource-based View, Relational View, Networks, Network Resources

* Dr. Stephan Duschek, Free University of Berlin, Institute of Business Administration, Boltzmannstrasse 20, D - 14195 Berlin, Germany, Phone : ++49 30 838-53783, Fax: ++4930838-56808, e-mail: duschek@wiss.fu-berlin.de.

** Article received: February 272004

Revised version accepted after double blind review: January 152005. 
Title VII of the Civil Rights Act of 1964 banned employers in the U.S. from paying individuals differently based on sex, but faculty were exempt from coverage until the Act was amended in 1972. Similarly, the Equal Pay Act of 1963 did not cover professional employees, including faculty, until 1972. In 1968 President Lyndon Johnson amended his earlier Executive Order 11246, which prohibited discrimination by all federal contractors, to include discrimination based on sex. In 1970, the Women's Equity Action League (WEAL) filed a class action complaint with the U. S. Department of Labor against colleges and universities in general under this Executive Order, forcing the attention of compliance agencies to the previously ignored sex discrimination ban in the Executive Order (Sandler 1973).

Since the early 1970s, considerable attention has been paid within institutions and in the literature in several fields, including especially education and economics, to the status of women in academe. Several review articles have documented the changes that have occurred over time on multiple fronts (e.g., Barbezat 2002; Bentley/ Blackburn 1992; Toutkoushian 1999). This paper extends these reviews by including the most recent data available on the representation of women among doctoral recipients and college and university faculties, and examines employment trends in tenure track positions by type of institution, academic rank, and salary, as well as trends in research productivity of men and women.

\section{Doctorates awarded to men and women}

Table 1 shows the recent history of doctoral degrees awarded in the U.S. (National Center for Educational Statistics 2005). Both the total number and the percent of doctorates earned by women have increased tremendously over the last 45 years, with women now earning almost half of the doctorates awarded. Projections are for the percent of doctoral degrees awarded to women to gradually increase a bit over the next decade, pulling even with men in 2012-13, and then pulling slightly ahead

Table 1: Doctoral degrees awarded to men and women in the U.S., 1959-60 to 20022003

\begin{tabular}{|l|c|c|}
\hline Year & $\begin{array}{c}\text { Total Doctoral } \\
\text { Degrees Awarded }\end{array}$ & Percent Earned by Women \\
\hline $1959-60$ & 9829 & 10.5 \\
\hline $1969-70$ & 29866 & 13.3 \\
\hline $1979-80$ & 32615 & 29.7 \\
\hline $1989-90$ & 38371 & 36.4 \\
\hline $1999-2000$ & 44808 & 44.1 \\
\hline $2002-2003$ & 46024 & 47.1 \\
\hline
\end{tabular}

Note: Data are from the Digest of Education Statistics 2004 ( NCES 2005).

However, women have historically been clustered in the "soft" fields, e.g., the humanities and social sciences, and some of the professions such as social work and nursing, while being relatively poorly represented in the "hard" fields such as science and mathematics, and other professions, such as law and medicine. Thus it is important to look at women's representation among doctorates by discipline to see if it has become closer to equal over time. Table 2, which expands and updates Table 2 in 
Toutkoushian (1999), provides a history of doctorates by sex by field from 1970-71 through 1994-95.

Table 2: Doctoral degrees conferred by field and sex in the U.S., 1970-71 to 2002-03

\begin{tabular}{|c|c|c|c|c|c|c|c|c|c|c|}
\hline \multirow[b]{2}{*}{ Field } & \multicolumn{2}{|c|}{$1970-71$} & \multicolumn{2}{|c|}{$1980-81$} & \multicolumn{2}{|c|}{$1990-91$} & \multicolumn{2}{|c|}{$2000-01$} & \multicolumn{2}{|c|}{$2002-03$} \\
\hline & Total & $\begin{array}{l}\% \\
\text { Fe- } \\
\text { male }\end{array}$ & Total & $\begin{array}{l}\% \\
\text { Fe- } \\
\text { male }\end{array}$ & Total & $\begin{array}{l}\% \\
\text { Fe- } \\
\text { male }\end{array}$ & Total & $\begin{array}{l}\% \\
\text { Fe- } \\
\text { male }\end{array}$ & Total & $\begin{array}{l}\% \\
\text { Fe- } \\
\text { male }\end{array}$ \\
\hline Agriculture & 1086 & $3 \%$ & 1067 & $12 \%$ & 1185 & $20 \%$ & 1127 & $34 \%$ & 1229 & $36 \%$ \\
\hline Architecture & 36 & $8 \%$ & 93 & $22 \%$ & 135 & $25 \%$ & 153 & $46 \%$ & 152 & $45 \%$ \\
\hline Biol. Sciences & 3595 & $16 \%$ & 3591 & $28 \%$ & 4034 & $37 \%$ & 4953 & $44 \%$ & 5003 & $46 \%$ \\
\hline Business & 774 & $3 \%$ & 808 & $15 \%$ & 1185 & $26 \%$ & 1180 & $34 \%$ & 1251 & $34 \%$ \\
\hline Communications & 145 & $13 \%$ & 182 & $41 \%$ & 272 & $45 \%$ & 370 & $49 \%$ & 398 & $55 \%$ \\
\hline Computer Sci. & 128 & $2 \%$ & 252 & $10 \%$ & 676 & $14 \%$ & 768 & $18 \%$ & 816 & $21 \%$ \\
\hline Education & 6041 & $21 \%$ & 7279 & $47 \%$ & 6189 & $58 \%$ & 6284 & $64 \%$ & 6835 & $66 \%$ \\
\hline Engineering & 3688 & $1 \%$ & 2608 & $4 \%$ & 5330 & $9 \%$ & 5604 & $17 \%$ & 5333 & $17 \%$ \\
\hline English & 1554 & $29 \%$ & 1040 & $52 \%$ & 1056 & $56 \%$ & 1330 & $60 \%$ & 1246 & $61 \%$ \\
\hline For. Languages & 854 & $37 \%$ & 708 & $54 \%$ & 647 & $58 \%$ & 818 & $64 \%$ & 749 & $62 \%$ \\
\hline Health Prof. & 518 & $16 \%$ & 868 & $43 \%$ & 1534 & $58 \%$ & 2242 & $64 \%$ & 3328 & $69 \%$ \\
\hline Mathematics & 1199 & $8 \%$ & 728 & $16 \%$ & 978 & $19 \%$ & 997 & $28 \%$ & 1007 & $27 \%$ \\
\hline Phys. Sciences & 4324 & $6 \%$ & 3105 & $12 \%$ & 4248 & $20 \%$ & 3911 & $26 \%$ & 3858 & $28 \%$ \\
\hline Psychology & 2144 & $24 \%$ & 3576 & $44 \%$ & 3932 & $61 \%$ & 5091 & $69 \%$ & 4831 & $69 \%$ \\
\hline Public Admin. & 174 & $24 \%$ & 362 & $41 \%$ & 430 & $56 \%$ & 574 & $54 \%$ & 596 & $56 \%$ \\
\hline Soc. Sciences & 3660 & $14 \%$ & 3122 & $27 \%$ & 3012 & $35 \%$ & 3930 & $41 \%$ & 3850 & $43 \%$ \\
\hline Visual Arts & 621 & $22 \%$ & 654 & $39 \%$ & 838 & $44 \%$ & 1167 & $51 \%$ & 1293 & $53 \%$ \\
\hline
\end{tabular}

Note: Data are from the Digest of Education Statistics 2004 ( NCES 2005).

In 1970-71, women earned less than one-quarter of the doctorates in most fields and less than 10\% in Agriculture, Architecture, Business, Computer Science, Engineering, Mathematics and the Physical Sciences (National Center for Education Statistics 2005). By 2002-03 the percentage of women in all these areas except math was substantially higher than the percentage of baccalaureate degrees earned by women had been in 1970-71. For example, the share of baccalaureates in agriculture earned by women had been $4 \%$ compared to $36 \%$ of the recent PhDs. Similar comparisons for the other fields were $14 \%$ and $45 \%$ in Architecture, $29 \%$ and $46 \%$ in Biology, 9\% and $34 \%$ in Business, $14 \%$ and $21 \%$ in Computer Science, . $8 \%$ and $17 \%$ in Engineering, and $14 \%$ and $28 \%$ in the Physical Sciences (National Center for Education Statistics 2005). Thus, the recent growth in PhDs earned by women reflects not only that women are going farther in the educational system now than in the past, but also shows that there has been a substantial movement of women into previously male dominated fields. Judged by this standard, even the two fields that currently have the lowest percentage of female doctorates, Computer Science and Engineering, show considerable progress. An important cautionary note, however, is that subfield differences may still exist but are masked in these aggregate figures (Toutkoushian 1999). For example, women have recently earned $69 \%$ of doctorates in psychology, but their representation in clinical psychology may still greatly outnumber their representation in experimental psychology. 


\section{Faculty representation by rank and overall}

Table 3 updates Stephan and Kassis (1997) data on the percent of full time faculty who were female, overall and by academic rank, for selected years from 1974-75 through fall 1991, by extending their data through 2003-04, also using the National Center for Education Statistics (NCES) data as did they. At the lowest ranks of Instructor and Lecturer, women now represent half the faculty. Within the standard, generally tenured or tenure track ranks of assistant through full professor, percent female has also grown substantially. In 2003-04 assistant professors were almost one half female, compared to about one quarter in 1974-75, and among associate professors the figure reached 38\% compared to 17\% in 1974-75. Even at the full professor rank the proportion of women rose from $10 \%$ to $24 \%$, though notably there continue to be increasingly fewer women at each of the progressively higher ranks.

Table 3: Full time faculty by academic rank in the U.S., selected years from 1974-75 through 2003-04

\begin{tabular}{|l|c|c|c|c|c|c|c|c|}
\hline Year & $\begin{array}{c}\text { All } \\
\text { faculty }\end{array}$ & $\begin{array}{c}\% \\
\text { Female }\end{array}$ & $\begin{array}{c}\text { Full } \\
\text { Prof } \% \\
\text { Female }\end{array}$ & $\begin{array}{c}\text { Assoc. } \\
\text { Prof \% } \\
\text { Female }\end{array}$ & $\begin{array}{c}\text { Assist. } \\
\text { Prof \% } \\
\text { Female }\end{array}$ & $\begin{array}{c}\text { Instructor } \\
\% \\
\text { Female }\end{array}$ & $\begin{array}{c}\text { Lecturer } \\
\% \\
\text { Female }\end{array}$ & $\begin{array}{c}\text { Other } \\
\text { Rank\% } \\
\text { Female }\end{array}$ \\
\hline $1974-75$ & 364097 & 23.71 & 9.8 & 16.7 & 27.1 & 40.5 & 39.7 & 33.2 \\
\hline $1977-78$ & 389033 & 25.39 & 9.5 & 18.2 & 31.6 & 50.6 & 43.4 & 34.7 \\
\hline $1980-81$ & 395992 & 26.43 & 10.2 & 20.4 & 34.8 & 51.7 & 46.3 & 36.1 \\
\hline $1985-86$ & 464072 & 27.60 & 11.6 & 23.3 & 35.8 & 42.6 & 47.8 & 38.4 \\
\hline $1991-92$ & 520324 & 31.75 & 14.7 & 27.7 & 39.7 & 47.3 & 52.4 & 42.7 \\
\hline $1995-96$ & 550822 & 34.60 & 17.8 & 31.8 & 43.6 & 50.4 & 54.3 & 44.4 \\
\hline $1999-2000$ & 590937 & 37.21 & 20.8 & 35.3 & 45.0 & 50.6 & 53.5 & 44.5 \\
\hline $2003-04$ & 631596 & 39.39 & 23.7 & 37.8 & 45.4 & 52.3 & 52.3 & 46.9 \\
\hline
\end{tabular}

Note: data for 1974-75 through 1991-92 are from National Center for Education Statistics Digest of Education Statistics, 1975 through 1993 as cited by Stephan and Kassis (1997). Data for 1995-96 are from National Center for Education Statistics, Digest of Education Statustics, 1999 (NCES 2000). Data for 1999-2000 are from National Center for Education Statistics, Digest of Education Statistics 2002 (NCES 2003). Data for 2003-04 are from National Center for Education Statistics, Digest of Education Statistics 2004 (NCES 2005).

While the relatively slow growth of percent of female full professors might on the surface suggest the possibility of bias in the promotion process, Hargens and Long (2002) have argued that factors such as the different age distributions of male and female faculty members, the existing heavily male representation among associate and full professors, rather low attrition from the faculty ranks, and the rate of growth or decline in the number of faculty positions all affect the speed at which parity in women's representation throughout the academic ranks can be reached. They note that the disproportionately large numbers of male full professors will need to retire before "fair" representation of women at that rank is possible. Thus, even with the large increase in the proportion of doctoral degrees earned by women in recent decades, the existing number of male full professors prevents the proportion of women at that rank from approaching parity at a more rapid rate. Toutkoushian (1999) makes similar arguments for rank and also concerning the speed with which hiring of males and females proportional to their availability in the applicant pool can lead to representation among employees that equals their proportions in the pool of potential employees. 


\section{Faculty representation by institution type}

Historically, women have been most heavily represented at the least research-intensive institutions, but that too has been changing. Bentley and Blackburn (1992) reviewed national statistics from 1969 through 1988 and reported that women had made gains in employment at research, doctoral and comprehensive I institutions, starting at $9.6 \%$ in 1969 and reaching 19.5\% in 1988. They reported, however, that women still held less than $15 \%$ of faculty positions at Research I institutions in 1988. Table 4 provides illustrative data for more recent years, 1992 and 1998, for men and women's faculty employment at institutions of various types, and of public or private control (U. S. Department of Education 2002b). We see that in the 1990s, almost half of the faculty at public two-year institutions were women, but there was a lower proportion of women at four-year institutions, both public and private. Within the four-year sector, women were 37 to $38 \%$ of the faculty at liberal arts and comprehensive institutions in 1998,33 to $36 \%$ at doctoral institutions, and 26 to $30 \%$ at research institutions. As Bentley and Blackburn (1992) found earlier, there has been continuing progress at all types of institutions except research universities. Nonetheless, the representation of women still tends to be inversely proportional to the research intensity of the institution.

Table 4: Representation of men and women by institution type and control in the U.S., 1992 and 1998

\begin{tabular}{|l|c|c|c|c|}
\hline \multirow{2}{*}{ Type and control } & \multicolumn{2}{|c|}{1992} & \multicolumn{2}{c|}{1998} \\
\cline { 2 - 5 } & Male & Female & Male & Female \\
\hline Public research & 76.7 & 23.3 & 70.5 & 29.5 \\
\hline Private research & 69.1 & 30.9 & 73.9 & 26.2 \\
\hline Public doctoral & 69.9 & 30.1 & 66.7 & 33.3 \\
\hline Private doctoral & 76.4 & 23.6 & 63.6 & 36.4 \\
\hline $\begin{array}{l}\text { Public } \\
\text { comprehensive }\end{array}$ & 66.1 & 33.9 & 61.7 & 38.3 \\
\hline $\begin{array}{l}\text { Private } \\
\text { comprehensive }\end{array}$ & 64.9 & 35.1 & 63.3 & 36.7 \\
\hline $\begin{array}{l}\text { Private liberal } \\
\text { arts }\end{array}$ & 61.1 & 38.9 & 62.2 & 37.9 \\
\hline Public 2-Year & 54.7 & 45.3 & 50.1 & 49.9 \\
\hline Other & 70.5 & 29.5 & 67.9 & 32.1 \\
\hline All & 66.8 & 33.2 & 63.7 & 36.3 \\
\hline
\end{tabular}

Notes: U.S. Department of Education, National center for Education Statistics, 1993 and 1999 National Study of Postsecondary Faculty (NSOPF:93; NSOPF:99) as reported in U. S. Department of Education, National Center for Education Statistics (2002b).

\section{Part time faculty and full time non-tenure track faculty}

Part time ranks have grown, as seen in Table 5 (NCES 2005). While three quarters of the faculty were full time in 1970, only somewhat more than half were full time in 2003. Benjamin (1999) cited NCES data showing that from 1976-77 to 1995-96 the percent of faculty who were part time increased from 31.4 to $40.8 \%$. However, the percent of women who were part time increased from $37.9 \%$ to $48 \%$ during the same 
time. This suggests a disproportionate number of women have been hired in the part time ranks, although we do not know whether this was by their preference. In any case, since part time faculty are typically not on the tenure track, the increase in their numbers can be viewed as part of a trend toward institutions hiring more of their faculty off the tenure track.

Table 5: Full and part time instructional faculty in Degree-Granting Institutions in the U.S., 1970-71 to 2003-04

\begin{tabular}{|l|c|}
\hline Year & \% full time \\
\hline $1970-71$ & 77.9 \\
\hline $1972-73$ & 76.0 \\
\hline $1976-77$ & 68.6 \\
\hline $1977-78$ & 66.1 \\
\hline $1981-82$ & 65.4 \\
\hline $1983-84$ & 65.0 \\
\hline $1987-88$ & 66.0 \\
\hline $1989-90$ & 63.6 \\
\hline $1991-92$ & 64.8 \\
\hline $1993-94$ & 59.6 \\
\hline $1995-96$ & 59.1 \\
\hline $1997-98$ & 57.5 \\
\hline $1999-2000$ & 57.5 \\
\hline $2001-2002$ & 55.5 \\
\hline $2003-04$ & 53.8 \\
\hline
\end{tabular}

Note: Data are from the Digist of Education Statistics, 2004 ( NCES, 2005). There was a change in method starting in 1987. Years in which percentages were estimated based on enrollment have been deleted.

Table 6 from the National Study of Postsecondary Faculty (U. S. Department of Education 2002a), a periodic national survey of faculty in higher education, casts light on the general question of hiring off the tenure track. It compares percentages of men and women in 1992 and 1998 who were at institutions with a tenure system and tenured, on the tenure track, or not on the tenure track, or who were at institutions without a tenure system. Within four-year institutions, where a tenure system has been the norm, Table 6 reveals that there has been a decrease in the proportion of full time faculty who are tenured or on the tenure track, from $78 \%$ to $74 \%$, with an increase in those who are not on the tenure track or who are at institutions that do not have a tenure system. It also shows that proportionally more women than men were not on the tenure track, or were at an institution without tenure during both years. Thus, the trend toward more part time faculty and more full time non-tenure track faculty is apparently undermining, to an extent, the progress women faculty have made in other respects, unless some women prefer positions without tenure or prospects of tenure.

Harper, Baldwin, Gansneder, and Chronister (2001) reported that institutions have increasingly turned to non tenure track faculty to teach large introductory courses for freshmen, and that many of these faculty members do not have doctoral degrees. 
Table 6: Percentage distribution of full-time four-year college instructional faculty and staff by tenure status and gender in the U.S., 1992-93 and 1998-99

\begin{tabular}{|c|c|c|c|c|}
\hline \multirow{2}{*}{ Gender } & \multicolumn{4}{|c|}{ Tenure Status } \\
\cline { 2 - 5 } & Tenured & $\begin{array}{c}\text { On Tenure } \\
\text { Track }\end{array}$ & $\begin{array}{c}\text { Not on Tenure } \\
\text { Track }\end{array}$ & $\begin{array}{c}\text { No Tenure } \\
\text { System }\end{array}$ \\
\hline All Faculty & & & & 17.5 \\
\hline 1992 & 55.0 & 23.4 & 20.7 & 4.1 \\
\hline 1998 & 53.9 & 19.7 & & 5.7 \\
\hline Males & & & 13.3 & 3.8 \\
\hline 1992 & 62.2 & 20.8 & 16.2 & 5.5 \\
\hline 1998 & 60.9 & 17.4 & & \\
\hline Females & & & 27.5 & 4.7 \\
\hline 1992 & 38.0 & 29.7 & 29.8 & 6.1 \\
\hline 1998 & 39.6 & 24.5 & & \\
\hline
\end{tabular}

Note: These data are from the National Study of Postsecondary Faculty 1993 and 1999 (NSOPF:93 and NSOPF:99) as reported in U. S. Department of Education, National Center for Education Statistics (2002a).

While these positions may be attractive to some because of their emphasis on teaching more than on research, they do limit future career opportunities. For example, even faculty with doctorates who hold these positions publish less than do faculty with full time tenure track jobs, on the average, which would limit future employment options. They also noted that quite a few of the non-tenure track faculty were "trailing spouses", members of dual career couples who had taken their position because the spouse or partner had a good opportunity at the institution. Interestingly, Bland, Center, Finstad, Risbey, and Staples (2006) found that tenure track faculty were more productive not only in research but also in teaching, measured by indices such as number of classes, enrollment, and contact hours, casting some doubt on the wisdom of the increased use of non-tenure track faculty.

\section{Tenure status}

Table 7 provides an historical view of the percentage of male and female faculty who have been awarded tenure by their institutions, from 1974 through fall 2003, based on the NCES Digest of Education Statistics. The first several columns provide the percent of faculty tenured at all degree granting institutions, showing that the difference in the percent of male and female full time faculty with tenure varied from about $17 \%$ to about $22 \%$ between 1974 and 1999, with a small increase followed by a decrease in the gap, but no noticeable progress over time. Beginning with the Digest of Education Statistics for 2003, there was a change in the definition of full time faculty or staff. The first two columns provide the original definition, which includes all full time faculty. The next two columns provide the percent of men and women tenured, based on all staff with full time instructional responsibilities. In the two years for which both sets of percentages are available here, the gender gap is about one to two percent smaller when calculated the new way. It should be noted that this approach also shows seven to nine percent fewer men and women being tenured when calculated this way, presumably because full time instructional staff includes staff who are not on the tenure 
track. As we have seen, their numbers have been growing, which may explain the suggestion of a downward trend in the percent of male instructional staff who are tenured.

Table 7: Percent of full time instructional faculty in the U.S. who are tenured, by sex

\begin{tabular}{|c|c|c|c|c|c|c|}
\hline \multirow[b]{2}{*}{ Year } & \multicolumn{4}{|c|}{ All Degree Granting Institutions } & \multicolumn{2}{|c|}{ Four Year Institutions } \\
\hline & $\begin{array}{c}\% \\
\text { Male } \\
\text { Faculty }\end{array}$ & $\begin{array}{c}\% \\
\text { Female } \\
\text { Faculty }\end{array}$ & $\begin{array}{c}\% \text { Male } \\
\text { Instructional } \\
\text { staff }\end{array}$ & $\begin{array}{c}\% \text { Female } \\
\text { Instructional } \\
\text { staff }\end{array}$ & $\begin{array}{c}\% \text { Male } \\
\text { Instructional } \\
\text { staff }\end{array}$ & $\begin{array}{c}\text { \% Female } \\
\text { Instructional } \\
\text { staff }\end{array}$ \\
\hline $1974-75$ & 58.2 & 41.0 & & & & \\
\hline $1975-76$ & 59.5 & 41.7 & & & & \\
\hline 1976-77 & 63.3 & 44.4 & & & & \\
\hline 1977-78 & 67.5 & 48.2 & & & & \\
\hline $1978-79$ & 67.8 & 46.8 & & & & \\
\hline $1979-80$ & 68.7 & 48.0 & & & & \\
\hline $1980-81$ & 70.0 & 49.7 & & & & \\
\hline 1981-82 & 64.6 & 44.1 & & & & \\
\hline $1982-83$ & 70.4 & 51.0 & & & & \\
\hline $1984-85$ & 71.1 & 51.8 & & & & \\
\hline $1985-86$ & 71.3 & 51.7 & & & & \\
\hline $1987-88$ & 70.5 & 50.2 & & & & \\
\hline $1989-90$ & 69.7 & 48.5 & & & & \\
\hline $1990-91$ & 67.8 & 45.3 & & & & \\
\hline 1991-92 & 70.1 & 49.1 & & & & \\
\hline 1993-94 & 71.0 & 49.9 & 62.6 & 42.7 & & \\
\hline 1994-95 & 71.3 & 50.3 & & & & \\
\hline $1995-96$ & 71.8 & 51.0 & & & & \\
\hline $1998-99$ & 70.6 & 51.8 & & & & \\
\hline $\begin{array}{l}\text { 1999- } \\
2000\end{array}$ & 69.0 & 50.9 & 59.6 & 43.1 & 58.3 & 38.5 \\
\hline 2001-02 & & & 56.5 & 41.5 & 55.2 & 36.9 \\
\hline 2003-04 & & & 56.0 & 41.5 & 54.6 & 37.2 \\
\hline
\end{tabular}

Note: Date for all institutions, 1974-75 through 1995-96 are NCES Digest of Education Statistics, 1976-1997 as cited in Stith-Willis (1999). Data for all institutions, 1998-99 and 1999-2000 are from NCES Digest of Education Statistics, 2002 (NCES, 2003). Data for four year institutions are from NCES Digest of Education Statistics, 2004 (NCES 2005).

Tenure is normally a possibility at four-year colleges and universities but less frequently so at two-year institutions. Thus the final two columns in the table provide a comparison of tenure rates of male and female full time instructional staff, within four-year institutions only. The gender gap is a little larger at four-year than at all institutions, but declined a percentage a year at both over the most recent three years. This would be a sign of improvement in the status of women, but may simply reflect an increase in men hired off the tenure track.

\section{Salary}

Table 8 provides information about salary trends experienced by men and women over time at all degree granting institutions and at public four-year colleges (NCES 
2005). Salaries are adjusted by the Consumer Price Index to reflect constant 2003-04 dollars. Overall, we see that salaries actually decreased in the 1970s into the 1980s, but in recent years have achieved levels that are a bit higher than those of the early 1970 s. At public four-year institutions, salaries are higher than at all institutions pooled. The gender difference in salaries expressed as a percentage of the average male salary increased at public four-year institutions from $17.7 \%$ in $1972-73$ to $20.3 \%$ in 1990-91, then dropped to about 19\% in 1994-95 where it stayed through 2003-04. Thus, in essence, there has been little or no change.

Table 8: Salaries of male and female faculty, all degree granting institutions and four year public institutions in the U.S., 1972-73 through 2003-04

\begin{tabular}{|c|c|c|c|c|}
\hline & \multicolumn{2}{|c|}{ All Faculty } & \multicolumn{2}{|c|}{ Four Year Public } \\
\hline Year & Male & Female & Male & Female \\
\hline $1972-73$ & 62,695 & 51,838 & 64,963 & 53,471 \\
\hline $1974-75$ & 58,576 & 48,401 & 60,788 & 49,696 \\
\hline $1975-76$ & 58,432 & 48,010 & 60,805 & 49,523 \\
\hline $1978-79$ & 56,443 & 46,401 & 58,757 & 47,887 \\
\hline $1979-80$ & 53,679 & 44,097 & 55,972 & 45,508 \\
\hline $1980-81$ & 52,630 & 42,956 & 54,800 & 44,271 \\
\hline $1981-82$ & 52,987 & 43,112 & 55,099 & 44,401 \\
\hline $1982-83$ & 54,347 & 44,103 & 56,237 & 45,269 \\
\hline 1984-85 & 56,623 & 45,642 & 58,667 & 47,176 \\
\hline 1985-86 & 58,647 & 47,159 & 61,199 & 49,047 \\
\hline $1987-88$ & 61,224 & 48,995 & 64,093 & 51,117 \\
\hline $1989-90$ & 62,673 & 50,098 & 65,708 & 52,328 \\
\hline $1990-91$ & 62,623 & 49,860 & 65,545 & 52,212 \\
\hline 1991-92 & 63,079 & 50,538 & 65,170 & 52,019 \\
\hline 1992-93 & 62,497 & 50,118 & 64,491 & 51,535 \\
\hline 1993-94 & 63,099 & 50,983 & 64,894 & 52,220 \\
\hline 1994-95 & 63,382 & 51,184 & 65,418 & 52,784 \\
\hline $1995-96$ & 63,614 & 51,637 & 65,582 & 52,980 \\
\hline $1996-97$ & 63,782 & 51,907 & 65,769 & 53,169 \\
\hline 1997-98 & 64,563 & 52,666 & 66,438 & 53,741 \\
\hline 1998-99 & 65,650 & 53,631 & 67,638 & 54,687 \\
\hline $1999-2000$ & 66,046 & 53,859 & 68,186 & 55,146 \\
\hline 2001-02 & 67,172 & 54,996 & 69,529 & 56,285 \\
\hline $2002-03$ & 67,573 & 55,288 & 69,817 & 56,327 \\
\hline 2003-04 & 67,509 & 55,425 & 69,290 & 56,183 \\
\hline
\end{tabular}

Note: Data are from NCES Digest of Education Statistics, 2004 (NCES, 2005).

Salaries are reported in constant 2003-04 dollars, adjusted by the Consumer Price Index

Salaries generally increase with academic rank and, as we have seen, women tend to be at lower ranks than men. Thus it is important to look at salary within rank as well. Table 9 (NCES 2005) displays average salaries by rank for men and women at all degreegranting institutions in constant 2003-04 dollars, from 1972-73 through 2003-04. 
Within ranks, the gender gap expressed as a percentage of the male salary mean decreased a bit in the 1970s, only to increase later to a current level that is a bit higher than it was in 1972-73 at each rank. The gap is larger at the full professor level than at the lower ranks, probably due to a larger gender gap in age and years of experience among full professors.

Table 9: Average salaries of men and women by academic rank in the U.S., 1972-73 through 2003-04, in constant 2003-04 dollars

\begin{tabular}{|c|c|c|c|c|c|c|}
\hline & \multicolumn{2}{|c|}{ Professor } & \multicolumn{2}{|c|}{ Associate Professor } & \multicolumn{2}{|c|}{ Assistant Professor } \\
\hline Year & Male & Female & Male & Female & Male & Female \\
\hline $1972-73$ & 84,396 & 74,434 & 64,004 & 60,106 & 53,005 & 50,035 \\
\hline $1974-75$ & 77,365 & 68,311 & 58,501 & 55,626 & 48,357 & 46,199 \\
\hline $1975-76$ & 76,848 & 68,144 & 57,744 & 54,910 & 47,563 & 45,373 \\
\hline $1978-79$ & 72,610 & 65,588 & 54,933 & 52,433 & 45,102 & 43,232 \\
\hline $1979-80$ & 68,729 & 62,109 & 51,899 & 49,480 & 42,476 & 40,687 \\
\hline $1980-81$ & 66,772 & 60,063 & 50,379 & 47,895 & 41,304 & 39,317 \\
\hline $1981-82$ & 66,835 & 60,189 & 50,529 & 47,994 & 41,575 & 39,284 \\
\hline $1982-83$ & 68,172 & 61,091 & 51,689 & 48,799 & 42,823 & 40,062 \\
\hline 1984-85 & 70,851 & 63,031 & 53,473 & 50,174 & 44,567 & 41,479 \\
\hline $1985-86$ & 73,250 & 65,416 & 55,191 & 51,817 & 46,334 & 42,695 \\
\hline $1987-88$ & 76,682 & 68,066 & 57,547 & 53,860 & 48,332 & 44,338 \\
\hline $1989-90$ & 78,628 & 69,853 & 58,815 & 54,913 & 49,509 & 45,564 \\
\hline $1990-91$ & 78,581 & 69,103 & 58,695 & 54,652 & 49,519 & 45,474 \\
\hline $1991-92$ & 78,760 & 69,506 & 58,994 & 54,890 & 49,777 & 45,864 \\
\hline $1992-93$ & 78,304 & 68,882 & 58,567 & 54,657 & 49,409 & 45,741 \\
\hline $1993-94$ & 78,726 & 69,676 & 58,836 & 54,953 & 49,373 & 46,032 \\
\hline 1994-95 & 79,241 & 69,972 & 59,023 & 55,214 & 49,394 & 46,214 \\
\hline $1995-96$ & 79,435 & 70,242 & 59,065 & 55,169 & 49,212 & 46,186 \\
\hline $1996-97$ & 79,883 & 70,451 & 59,088 & 55,159 & 49,026 & 46,082 \\
\hline $1997-98$ & 81,077 & 71,294 & 59,876 & 55,914 & 49,493 & 46,601 \\
\hline 1998-99 & 82,855 & 72,649 & 60,880 & 56,941 & 50,498 & 47,381 \\
\hline $1999-2000$ & 84,067 & 73,736 & 61,490 & 57,260 & 51,020 & 47,671 \\
\hline $2001-02$ & 87,051 & 75,758 & 62,973 & 58,677 & 52,757 & 48,900 \\
\hline $2002-03$ & 88,077 & 76,669 & 63,587 & 58,979 & 53,588 & 49,438 \\
\hline 2003-04 & 88,254 & 76,749 & 63,465 & 59,093 & 53,660 & 49,696 \\
\hline & & & & & & \\
\hline
\end{tabular}

Note: Data are from NCES Digest of Education Statistics, 2004 (NCES, 2005).

Salaries are reported in constant 2003-04 dollars, adjusted by the Consumer Price Index.

Some of the difference between men and women in salaries might be due to their differences in disciplines. As an example of disciplinary differences in pay, Table 10 (NCES 2005) shows that 1998-99 salaries varied considerably at all institutions considered together, with those in health topping the range, and fine arts at the bottom. Several fields with a large proportion of women, i.e., education and humanities, were toward the bottom in this distribution of salary levels, while engineering, where men 
predominate, was close to the top. The ranking was the same in public research universities, except that business faculty earned considerably higher salaries compared to their colleagues in other disciplines there than within all institutions combined. Generally, salaries were higher at public research universities than they were overall. Table 11 (NCES 2005) summarizes 1998-99 mean salaries by institution type and control, indicating that on average salaries are higher, the more research intensive the institution. Among research and doctoral institutions, those that are privately rather than publicly controlled have higher average faculty salaries.

Table 10: Mean 1998-99 salaries of full time faculty at all degree granting institutions and at public research universities by broad discipline group in the U.S.

\begin{tabular}{|l|c|c|}
\hline Field & All degree granting institutions & Public research universities \\
\hline Health & 75,238 & 85,518 \\
\hline Engineering & 63,401 & 69,867 \\
\hline Social Sciences & 58,714 & 69,074 \\
\hline Agric., Home Economics & 58,434 & 67,336 \\
\hline Natural Sciences & 57,331 & 65,951 \\
\hline Business & 55,837 & 69,241 \\
\hline Other & 52,150 & 59,896 \\
\hline Education & 47,789 & 53,412 \\
\hline Humanities & 47,697 & 53,929 \\
\hline Fine Arts & 45,655 & 49,342 \\
\hline
\end{tabular}

Note: Data are from NCES Digest of Education Statistics, 2004 (NCES, 2005).

Table 11: Mean 1998-99 salaries of full time faculty by institution type and control in the U.S.

\begin{tabular}{|l|c|c|}
\hline Institution type & Public & Private \\
\hline Research & 66399 & 81574 \\
\hline Doctoral & 65466 & 70240 \\
\hline Comprehensive & 50143 & 49374 \\
\hline Liberal Arts & & 43600 \\
\hline 2 Year & 44636 & \\
\hline
\end{tabular}

Note: Data are from NCES Digest of Education Statistics, 2004 (NCES 2005).

\section{Productivity}

Evaluation of the gender equity of initial hiring, setting of salaries, and decisions concerning rank and tenure requires a comparison of men and women who are alike on factors that legitimately affect these decisions. There is a good deal of evidence that both salary and rank are heavily influenced by the individual's productivity in terms of publications (Astin/Milem 1997; Fairweather 1993; Long/Allison/McGinnis 1993), and that external grants are also factors (Fairweather 1993; Ferber/Hoffman 1997; Loeb/Ferber/Lowry 1978). For this reason, productivity of male and female faculty has been studied quite extensively. Indeed, when women's status became an issue in the late 1960s and early 1970s, their publication rate was found to lag behind that of men (e.g., Bayer 1970; Loeb/Ferber 1973), and later studies have also found a productivity gap (e.g., Astin/Milem 1997; Cole 1979; Persell 1983; Sonnert 1995), dubbed 
"the productivity puzzle" by Cole and Zuckerman (1984). Creamer (1998) reviewed research about productivity of publications, citing seven comparisons of men's and women's article productivity in different academic disciplines in the 1980s and 1990s. In all seven she examined, men produced a larger mean number of articles than did women, although in only three of the seven was the difference significant at the .05 level. She pointed out that the gap is typically quite small when a short-term measure of productivity, such as a publication count for a two-year period, is used.

The productivity gap has been investigated with regard to a number of factors on which men and women faculty tend to differ that might influence it, e.g., the research intensity of the institutions where men and women are employed, the age of the faculty concerned, the disciplines in which they are employed, and the household and childcare responsibilities that they have. Productivity varies by type of institution, and by academic discipline, with the highest publication rates occurring at research universities and in the hard sciences (see Creamer's 1998 review of the relevant literature). Thus, women's concentration at less research intensive institutions and in the humanities and social sciences, are confounding factors in studying the productivity gap.

According to a number of different analyses the gap has narrowed over time. Bentley and Blackburn (1992) compared results from national surveys conducted in 1969 by the American Council on Education, in 1975 by the Carnegie Council, in 1980 by the Higher Education Research Institute, and in 1988 by the National Center for Research to Improve Postsecondary Teaching and Learning. They found that twoyear publication differences between men and women had narrowed over this twenty year period. Similarly, Sax, Hagedorn, Arredondo, and Dicrisi (2002) compared the production of total professional writings reported by men and women faculty in the 1972-73 American Council on Education survey, the 1989-90 survey of the Higher Education Research Institute, and the 1998-99 National Survey of Postsecondary Faculty. They found that publications for both men and women had increased over those years, a finding also reported by others (e.g., Bentley/Blackburn 1990; Dey/Milem/ Berger 1997). More important to the present purpose, they found that the gender gap had declined, except when comparing the most prolific faculty who had published five or more items in the previous two years. Fewer men and women published nothing, and the difference between the percent of men and women publishing nothing was cut in half. More men and women had published 1-2 items, and there was essentially no difference in the percent of men and women in this category in 1998-99. A small gap in the percent publishing three or four items remained, but again, it was cut in half compared to 1972-73.

Xie and Shauman (1998) used the Carnegie Commission survey from 1969, the American Council of Education survey from 1972-73, and the National Surveys of Postsecondary Faculty from 1987-88 and 1992-93 to examine productivity trends over time. They argued for the use of a short-term rather than a cumulative measure of productivity for several reasons, including the fact that a disproportionate number of women were hired in recent years compared to male faculty, so that comparisons of cumulative publications over the career would be biased. Using a two-year count of refereed and non-refereed journal articles, chapters in books, books, and monographs, they too found a decrease in the gender gap in publications over time. However, the 
gap remained significant, with women publishing fewer items, even after controlling for field of study, time between baccalaureate and $\mathrm{PhD}$ as a measure of motivation and organization, and years of experience beyond the doctoral degree. They also performed analyses using additional controls, including type of institution and academic rank, but these two factors clearly could be the consequences rather than or as well as the causes of productivity, and thus the results are not reported here. Bellas and Toutkoushian (1999) found that men and women are more productive when they work more hours per week overall or allocate a higher proportion of their work time to research. The second factor might result from differential assignments of teaching to male and female faculty made by institutions. Nonetheless, controlling for these as well as a number of other factors, they still found a significant gender difference in research output. The conclusion seems clear that the gap has been reduced, but there is still a difference between men and women in publication productivity, even after some relevant factors have been taken into account. However, the productivity gap appears to vary by discipline. For example, Stack $(1994,2002$, and 2004) found no productivity difference between men and women in sociology, criminal justice, or social sciences in general. He suggests that fields with relatively high proportion of women may have better developed "women centered research networks", more collaboration among women scientists, and less discrimination.

Productivity varies considerably across types of institutions. It is highest at research I universities, and declines as institutions are successively lower in research intensity, from research I to research II, doctoral I and II, comprehensive universities, liberal arts colleges, and two year colleges (see, for example, Bentley/Blackburn 1990; Dey/Milem/Berger 1997). While it is to be expected that institutions that demand more research productivity would hire and retain faculty who are and continue to be more productive than average, there is also evidence of the reverse effect, that the reward structure shapes faculty behavior. For example, Long and McGinnis (1981) found that after controlling for prior publications and citations, biochemists who were with a single employer for nine years, published less if employed at a teaching institution or an industrial employer than if employed at research universities. This result suggests that the employing organization helps to shape productivity. In fact, Long (2001: 6) concluded that “(s)ome of the difference in women's status in academia can be explained by lower productivity, as measured by publications. It seems clear, however, that differences in the positions held by women are likely the cause of lesser productivity, rather than the other way around."

The effects of marriage and children on productivity have been studied increasingly in recent years, in order to explain the productivity gap between male and female faculty. Two of the main findings are that fewer female than male faculty members are married (e.g., Astin/Milem 1997; Perna 2005b), and that the effects of marriage on productivity are not clear. Creamer (1998) found ten articles on the relationship, five showing no effect, two with a significant negative relationship, and three with a significant positive relationship between marriage and productivity. In more recent work, Toutkoushian (1998b) found that both men and women published more articles if they were married, and Bellas and Toutkoushian (1999) found that marriage had a positive effect on three different measures of research productivity after sex, race, 
number of dependents, time spent in teaching and service, hours worked per week, institution type, and rank were all controlled. Thus, married faculty appeared to be more productive per unit of time worked.

Results are also mixed concerning the effects of parenthood on productivity. For instance, in her review Creamer (1998) found a similar mix of non-significant, positive and negative effects for parenthood as for marriage. Stack (2004), however, pointed out that little of this past research controlled for age of children, and some did not differentiate between children living in the household and those who do not. Using 1995 data from the Survey of Doctoral Recipients, he studied five-year article productivity of $\mathrm{PhDs}$ in academic jobs with at least five years of post $\mathrm{PhD}$ experience. The effect of children in the home was broken out into preschoolers only, children 6-10 only, teens only, adult children only, children up to 10 years old only, children from 6 to teenage only, and teens and adults only. Controlling for these factors, institution type, field, primary position in teaching or administration, rank, hours worked per week, federal support for research, years to $\mathrm{PhD}$ as a measure of motivation, years since $\mathrm{PhD}$ and its square, marital status, and race, he found that women published less then men even after controlling all of these other factors. Children up to 10 years old exerted a positive influence on productivity, but there was a female by preschooler interaction such that the presence of preschoolers was positive for men and negative for women. Women with only preschoolers in the household published less than did other faculty. Children older than ten had no effect. Limiting the sample to academicians with doctorates in the social sciences, he found no overall gender gap, using the same controls listed above, but women with both preschoolers and children under 11 were less productive than were others. This study suggests a negative effect of young children on women's productivity.

Suitor, Mecom, and Feld (2001) studied the relationship of household labor with productivity of men and women faculty at one research university, finding that married tenure track men spent significantly more time on research and worked more hours per week than did married tenure track women. Women, on the other hand, spent significantly more time on household labor than did men. Among tenure track faculty with children at home, men spent more time on research, less time on household labor, and considerably less time on childcare than did women. Totaling household and childcare, women spent 20 hours per week more than did men with children in the house. A significant interaction effect indicated that women with children at home experienced decreased productivity related to household labor. Thus, these two recent studies suggest negative effects of children for women, at least when children are young.

\section{Evaluation of scholarship and faculty performance}

So far we have examined the quantity of scholarship produced by men and women in academe. An additional question, however, concerns the quality of that scholarship. Does the evaluation of scholarship suggest that there is a difference in quality and is there evidence that there might be bias in the evaluation of women's and men's scholarship? 
Citations are generally taken as one measure of high quality in scholarly work (Braxton/Bayer 1986; Creamer 1998). Long (1992) found that female biochemists averaged more citations per paper than did male biochemists, and Cole and Zuckerman (1984) found no difference in the same measure for male and female physical scientists and mathematicians. Thus, the evidence to date suggests that the quality of the scholarship produced by men and women is about the same, as indexed by citations per item. Concerning the objectivity of citations themselves, Ferber (1986) found that men cited men more than women did, while women cited women more than men did, suggesting the possibility of bias in this process.

There have been a number of studies of the effect on performance evaluation of the gender of the individual being evaluated, with mixed results. Overall, however, there is evidence for a pro-male bias (see Bauer/Baltes 2002). For example, Bauer and Baltes 2002, had college students rate professors from descriptive statements that were variously identified as either male or female. They used the Women as Professor Scale (WAPS) to determine the extent to which the students held stereotypic views of women as college professors, and intervened with some subjects by having them perform a structured free recall task in which they spent some time recalling and writing down both the positive and negative aspects of the described performance before rating it. They found that, in the absence of intervention, women were evaluated less accurately and less positively by raters with strong traditional stereotypes of women but with the intervention, there was no difference in the ratings of those who did and did not hold these stereotypic views. Thus, they demonstrated that the tendency of individuals holding traditional stereotypic views of women to under-evaluate their performance can be reduced by having them recall details of the performance. The authors noted, however, that the task involved only a small amount of information about the ratees. Nonetheless, the results might be relevant to situations such as fairly brief personnel selection interviews and evaluations based on refereeing a single paper, or quickly reviewing materials for the annual salary evaluation of faculty.

A recent study by Steinpreis, Anders and Ritzke (1999) compared the judgments of a national sample of male and female psychologists of four curricula vitae, two identical CVs of a candidate for a tenure track position, and two for promotion to tenure. In each case the only difference was that one candidate had a female name, the other a male name. More men and women voted to hire the male applicant and both more frequently judged the teaching, research and service records of the male to be adequate. On the other hand, both men and women were equally likely to judge the male and female tenure candidates as being qualified for tenure. Even here, though, they made four times as many cautionary comments about the woman than the man, including "I would need to see evidence that she had gotten these grants and publications on her own" (Steinpreis et. al. 1999: 523). The authors believed the CV for the tenure candidates was stronger for that purpose than was the $\mathrm{CV}$ of the job candidate and suggested that an exemplary record may "buffer gender bias" (Steinpreis et. al. 1999: 524). They concluded that gender bias may influence evaluations and that men and women are equally capable of such bias, even among psychologists who might be expected to show less gender bias than other samples because they are likely to be aware of research on gender bias. That the bias was nonetheless manifest is indeed disturbing. 
Wenneras and Wold (1997) also found evidence of differences in the performance evaluations received by men and women. Fellowship applicants to the Swedish Medical Research Council were rated for "scientific competence", and the authors predicted these ratings from six productivity measures based on number of publications, first-authored publications, and citations, as well as other factors, e.g., nationality, field, and university affiliation. Overall, the reviewers gave female applicants lower scores. The six measures were used individually in regression models, resulting in three significant models. These predicted competence scores from citations of firstauthored works, and average citations per paper in a year of the journals in which all or, alternatively, first-authored papers were published. In all three models, both being male and having an affiliation with a member of the review committee were significant positive predictors of competence rating, with the citation index held constant, although reviewers who had substantial personal ties to the person being reviewed were disqualified from evaluating that individual. The authors pointed out that the United Nation had recently designated Sweden as the world's leader in equal opportunity for women, so there is no reason to expect there would be less bias in other countries. Like the study of academic psychologists cited above, they suggest gender bias in performance evaluations, even in a relatively benign environment.

\section{Academic rank relative to credentials}

Since men and women differ in productivity, years of academic experience, and other factors relevant to decisions concerning promotion and tenure, these factors need to be taken into account in order to evaluate whether equally qualified men and women tend to hold the same academic rank.

Equity in rank advancement has not been studied as much as salary has. However, there are a good many studies within single institutions and in specific disciplines, as well as several that compare the results across years using national data sets. Those done during the 1970s found slower promotion of women than of men, after controlling for factors such as highest degree, years of experience, and publications (e.g., a national study by Bayer and Astin 1975, and an institutional analysis by Loeb/ Ferber/Lowry 1978). In another early study, Cole (1979), who used publications and citations to account for productivity, found residual differences favoring men in biology, chemistry, psychology, and sociology. Further, the discrepancies in rank tended to be larger within more prestigious departments. Using a more recent sample, Sonnert (1995) found differences in rank for similarly qualified men and women in math, physical sciences, engineering, social sciences, and humanities, but no difference in biology, suggesting that equality had been achieved in that field. Smart (1991) used data from the Carnegie Foundation for the Advancement of Teaching 1984 survey to study rank, controlling highest degree, years since degree, institutional prestige, discipline type, male domination of the discipline, and activities (teaching, research, administration) of the faculty member. The direct effect of gender in depressing women's rank with these controls (but with no control for productivity) was significant at the .001 level.

Ransom and Megdal (1993) compared women's and men's attainment of associate or full professor rank across time from national surveys for 1969, 1973, 1977, and 1984. With controls that included highest degree, years of experience, seniority, arti- 
cles and books, women's rank advancement was slower than men's in all four years. The size of the effect appears to have been larger in 1969 than in later years, but no statistical test was provided. Ginther and Hayes (2003) compared the probability of promotion to tenure for two cohorts of humanities doctoral recipients, 1975-1979 and 1980-1989, controlling for variables that included age, race, marital and parental status, years of experience, publications, and field within the humanities. Females were less likely to be tenured than were equivalent males in the earlier cohort, but the difference between the groups, while of nearly the same size, was no longer statistically significant in the later years. In a study of the careers of men and women in science and engineering that covered 1979 through 1995 Long (2001), who controlled for field, institution type, and career age (years since $\mathrm{PhD}$ and its square) but not for productivity, found unexplained differences in the attainment of both tenure within 10 years of the $\mathrm{PhD}$ and the full professorship within twenty years; in both instances the differences were smaller in the later year (the overrepresentation of men among full professors dropped from $20 \%$ to under 10\%) but still significant. Similarly, the overrepresentation of men among the tenured professors dropped from 17\% in 1979 to 4\% in 1995. It is possible that if productivity had been controlled, the study would have provided evidence that by 1995 both tenure and rank were fairly awarded.

Several researchers used the National Study of Postsecondary Faculty to examine equity in academic rank and tenure through the 1990s (Toutkoushian 1999; Perna 2001b; Perna 2005a). After controlling for race, years of experience, experience squared, and career publications (articles, books, book chapters), Toutkoushian (1999) found that there were residual gender differences in the likelihood of being tenured, being a full professor, and being an associate or full professor in 1992-93, but not of being at the associate professor level. Perna (2001b) used the same data set to study full time faculty working at 4 year institutions, the same basic selection criteria, and controls similar to those employed by Toutkoushian (1999), and also found that women were significantly less likely to be tenured or to achieve the rank of full professor than were similar men in 1992-93. Using a similar sample for 1998-99 and introducing additional controls for marital and dependent status, she further found that women were more likely than similar men to hold non-tenure track than tenured positions (Perna 2005a) or to be tenure track rather than tenured (although this latter effect was significant only at the .05 level), and, after the controls were in place, women had a higher likelihood than men to hold a rank other than full professor.

Bain and Cummings (2000) provided an analysis of the likelihood of achieving full professor rank at four-year institutions that spans 15 countries, using data from the Carnegie Foundation International Survey of the Academic Profession, between 1991 and 1992. Controlling factors such as full time status, time spent on research, a count of scholarly products, seniority, and highest degree, they found that women were less likely than were similarly qualified men to have achieved full professor rank. Thus, at least as late as the early 1990s, the problem of unequal treatment of academic men and women was not limited to the United States. They conclude that the two factors that cut across societies and institutional types are that women are on average younger because they have been entering academia in growing numbers in recent years, and that they are somewhat less productive than men. It should be noted, however, that 
they found a gender gap in achievement of the full professor rank even after controlling for seniority and productivity, suggesting a residual problem beyond those two.

\section{Salary relative to performance}

It is clear from the data presented earlier that academic women earn less than men do, even within the same rank, but it is not clear to what extent other factors such as the relative youth of women due to their increasing proportion among recipients of doctoral degrees since the early 1970s, their location in lesser institutions and disciplines that pay less, as well as their somewhat lower productivity, might account for most or all of the salary gap. A host of salary equity studies has investigated this question within single institutions and within disciplines since the late 1960s. In addition, national data sets have been used to analyze the same question beginning with Bayer and Astin (1968).

Relatively recently, Barbezat (2002) has provided an excellent review both of institutional salary equity studies and those using national data sets through the early 1990s, summarized here. In the 1970s, institutional studies predominated, and most found salary gaps after controlling factors such as publications, rank, highest degree, and years since the highest degree. One pair of studies found a residual difference of $\$ 846$ in 1969-70 and of \$902 at the same large research institution in 1974-75 (Loeb/ Ferber 1971; Loeb/Ferber/Lowry 1978). Katz (1973) found a difference of $\$ 2410$ in 1969-70, also at a large institution, while Gordon, Morton, and Braden (1974) found a difference of $10 \%$ in 1970 . Ferber and Green (1982) found a differential of $\$ 2200$ between similarly qualified recently hired male and female faculty from fall 1975 through fall 1978. Gifford (1980) found a salary gap only between men and women hired prior to 1972, but not among those hired later. While the gap appears to have ranged from about $\$ 900$ to over $\$ 2000$ in the 1970 s according to this review, depending on the institution and also on the controls used in the study, there were several exceptions, including Martin and Williams (1979) and Koch and Chizmar (1976). The former study found no sex difference in salary after equity adjustments were made; the latter reported finding evidence of discrimination against men after such adjustments. Bayer and Astin (1968) examined 1968-69 salaries of faculty in the sciences, using a national NSF data set. Like the preponderance of the institutional studies, this survey discovered a significant salary gap regardless of rank, major field, or work setting. Another national study of salaries in 1968-69 (Astin/Bayer 1973) not reviewed in Barbezat (2002) used the Carnegie-ACE survey of faculty and similarly found that after controlling for a large set of variables sex differences in salary were still significant.

Barbezat (2002) compared the results of three national studies that together cover the period 1969 through 1989 and use various data sets to estimate trends in salary differentials (Ashraf 1996; Barbezat 1991, Ransom/Megdal 1993). These studies show a consistent pattern of greater differentials in 1969, before affirmative action programs were initiated than in the late 1970s. These studies predicted the log of salaries and thus to convert the regression coefficient for the variable "female" into a percentage salary difference, it is necessary to exponentiate it. Using this method, the gap had narrowed from 11 to $15 \%$ to 6 or $7 \%$ by the late 1970 s. The estimates of thee studies are not as consistent through the 1980s. Ashraf 1996, found an insignificant regression 
coefficient of -.01 for 1984, although the other two estimates for 1984 suggest a differential of about $7 \%$. Barbezat (1991) estimated a gap of about $8 \%$ for 1988, and about 6\% for 1989, as did Ashraf (1996) These coefficients suggest little or no progress through the 1980 s.

Several reports of the National Center for Education Statistics provide information about salary equalization through the 1990s, using the National Study of Postsecondary Faculty for 1993 and for 1999 (NSOPF: 93 and NSOPF: 99). In the first of these, Nettles, Perna, and Blackburn (2000) studied 1992-93 salaries of full time faculty at two- and four-year institutions. Using a wide variety of controls, including race, field, institution type, level of instruction, highest degree, years since degree, age, time spent on research and on teaching, recent publications, rank and tenure, the salary penalty for females was 7.6\%. The later study (Bradburn/Sikora/Zimbler 2002) also involved faculty at all degree granting institutions and used similar controls, arriving at an estimate of an $8.7 \%$ gap. These studies, unlike most others, include full time faculty at two-year as well as four-year colleges.

Another series of studies linked the earlier data described by Barbezat (2002) with later data from the 1990s. Barbezat (1991) established a common set of variables and models to analyze five national faculty surveys that were conducted between 1968 and 1989, restricting all analyses to four-year college faculty at the ranks of assistant through full professor. Some variables were slightly different for one survey or the other. Using a full model, controlling for advanced degree, eleven month contract, race, age, administrative activity, experience, experience squared, teaching vs. research emphasis, and where possible, geographic region, as well as articles and books published, discipline, and type of institution, but without control for rank, she estimated that the salary gap fell from $18 \%$ in 1968 to $3 \%$ in 1977 , then rose to $7 \%$ in 1984 , a male advantage that remained in 1989. Toutkoushian (1998a) extended this work by running similar models for salary data from 1992-93 (NSOPF: 93). He found a 7\% disadvantage for women, comparable to Barbezat's estimates from the 1980s, and thus, no evidence of any improvement. However, when analyzing faculty who were 40 years old or less, he found a smaller wage gap in both 1987-88 and 1992-93 for them than for older women. Thus, the gap may have fallen for younger women. Perna (2001a) used the same NSOPF: 93 data set as Toutkoushian, but divided faculty by experience within ranks, estimating separate equations for assistant professors with 12 years and 3-6 years of experience, associates with 7 to 12 and 13-20 years, and full professors with 13-20 and more than 20 years of experience. At each rank the regression coefficient for gender was smaller for the younger group, and was not significant for the younger cohorts within each of the ranks. She concluded that this could either mean that younger women have a level playing field, or it could reflect the much more careful evaluation commonly used for hiring and promotion decisions, as opposed to annual salary decisions. She suggested that these careful evaluations might help to "equalize" salaries of men and women, which may then drift apart again over the intervening years.

At least three studies have also compared the salary gap from 1992-93 and 199798 using the NSOPF: 93 and NSOPF: 99 data sets. In her dissertation, Keller-Wolff (2003) studied full time faculty at four-year colleges and universities, using a large 
number of covariates. These included some that may not be legitimate bases for salary decisions, e.g., marital status, dependents, climate for women, views on whether teaching or research should predominate in rank decisions, and proportion of women in the field. She also used rank as a predictor, which is often not included because it is possible that if salary decisions are biased, rank decisions will be as well (e.g., Hoffman 1976). However, Keller-Wolff's investigations of rank differences produced no evidence of significant gender bias, and thus she included it as an independent variable in her salary models. The differences between her models and those more commonly used to investigate salary differences are probably a major reason why her results are somewhat different from those of Toutkoushian and Conley (2005) and Barbezat and Hughes (2005), using the same data set.

Barbezat and Hughes (2005) estimated a residual gap of about 4\% in 1998-99, about half of the $8 \%$ estimated by Toutkoushian (1998a) for 1992-93 using similar covariates, suggesting that some progress had been made toward increasing salary equity. Toutkoushian and Conley (2005) estimated the same models for the 1998-99 that Barbezat (1991) and Toutkoushian (1998a) had estimated for earlier years, limiting their samples in comparable ways as well. Their salary gap for 1998-99 fell to about $4 \%$ from Toutkoushian's earlier estimate of $8 \%$, and they found the difference between the two estimates to be significant at the .01 level regardless of which of Barbezat's five models they used. They concluded that although the gap was still significant, progress toward equity had been made.

Keller-Wolff (2003) on the other hand, included all full time tenured and tenure track faculty at four year institutions in her analyses of the same two NCES data sets, and her estimates are about 4\% in both 1992-93 and 1998-99. However, given her use of covariates not commonly seen as legitimate for salary determination, the studies discussed above may be assumed to provide more reliable estimates concerning progress in the 1990s and to justify the conclusion that progress has been made, although a gap still exists. One final point is that both Keller-Wolff (2003) and Toutkoushian and Conley (2005) found larger salary gaps at Research I and II institutions than in other types of institutions. In fact, with Keller-Wolff's methodology, the gap was significant only at the Research institutions.

\section{Summary and Conclusions}

In the past thirty five years, women have made large strides in entering academic fields that were previously predominantly male, earning doctorates, attaining full time faculty positions at all types of institutions, increasing scholarly productivity, and in narrowing the gap in salaries and ranks. However, not all gender imbalances and gaps have been erased. Overall, women are now earning about half of the doctorates awarded annually in the U.S., and comprise a larger proportion within all fields, but they are still far better represented in the humanities and social sciences than in math, the hard sciences, and engineering, where they recently earned $17 \%$ of doctorates. Even so, the increase in engineering degrees from 1\% in 1970-71 is encouraging.

Also, women now represent about one-half of assistant professors, instructors, lecturers, and "other" faculty, commensurate with their availability in the pool of new doctorates. There has been considerable progress at the higher ranks, as well, but the 
highest rank of full professor is still only about one-quarter female, in part because of the large number of older men at this rank who will need to retire before the percentages can shift in a major way. Also, women are still better represented at less research intensive institutions, with about half of the faculty at two year colleges now female, but under $40 \%$ at liberal arts and comprehensive institutions, fewer at doctoral universities, and even fewer at research universities. At private research universities the percentage of female faculty actually decreased in the 1990s compared to increases at all other types of institutions.

It must also be noted that a smaller proportion of full time faculty are tenured now than in the past, so that a recent decrease in the gender gap at four-year institutions has partly resulted from a decline in the proportion of men with tenure. Also, the salary gap between men and women has been approximately constant from 197273 through 2003-04, and within ranks, the gap is a bit higher in 2003-04 than in 197273. The gap is also higher at the full professor level than at the lower ranks, although this is probably in part due to the large age and experience difference between men and women at that rank. Further, salary varies a good deal by discipline and type of institution, and so do the proportions of female faculty, so these factors need to be taken into account in evaluating the equity of salary levels. In addition, while women still generally publish less than men even after controlling for other factors that affect productivity, such as field of study and years since earning the doctorate, the productivity gap has narrowed over time and in fields where women are heavily represented may have disappeared entirely, in spite of continued under representation of women at the most research oriented institutions, where productivity is highest. There is also some evidence that presence of young children in the home inhibits women's but not men's research productivity, and that this is related to time spent in household labor. Overall, then, the productivity gap has decreased, and the gap that remains has been, at least in part, explained by the disadvantages women still face.

Studies of rank that control relevant factors on which men and women differ still find unexplained differences in rank, including holding a tenure track as opposed to a non-tenure track position. Thus, there is continuing evidence of some difficulty on this front.

Overall, the number of citations for articles is the same for men and women on a per article basis, but there are indications that the evaluation of scholarship and other performance measures may be biased, with judgments of women's work harsher by both men and women, especially when the knowledge of an individual's work is fairly cursory. To the extent that such bias influences salary and hiring deliberations, this would explain some of the residual differences in men's and women's status.

All told, a great deal of progress has been made since the initiation of affirmative action requirements in higher education. While there are still trouble spots, a great deal of the accumulated evidence shows that the status of women in higher education is much improved now as compared to thirty five years ago.

\section{References}

Ashraf, J. (1996): The influence of gender on faculty salaries in the United States, 1969-1989. In: Applied Economics, 28(7): 857-864. 
Astin, H./Bayer, A. (1973): Sex discrimination in academe. In: A. S. Rossi \& A Calderwood (Eds.): Academic Women on the Move. New York, NY: Russell Sage Foundation: 333-356.

Astin, H. S./Milem, J. F. (1997): The status of academic couples in U.S. institutions. In: M. A. Ferber/J. W. Loeb (Eds.): Academic Couples: Problems and Promises. Urbana, IL: University of Illinois Press: 128-155.

Bain, O./Cummings (2000): W. Academe's glass ceiling: Societal, professional-oranizational, and institutional barriers to the career advancement of academic women. In: Comparative Education Review, 44(4): 493-514.

Barbezat, D. (1991): Updating estimates of male-female salary differentials in the academic labor market. In: Economic Letters, 36(2): 191-195.

Barbezat, D. (2002): History of pay equity studies. In: J. F. Volkwein (Series Ed.) and R. K. Toutkoushian (Vol. Ed.): New Directions for Institutional Research: No. 115. Conducting Salary-Equity Studies: Alternative Approaches to Research: 9-39.

Barbezat, D. A./Hughes, J. W. (2005): Salary structure effects and the gender pay gap in academia, Research in Higher Education, 46(6): 621-640.

Bauer, C. C./Baltes, B. B. (2002): Reducing the effects of gender stereotypes on performance evaluations. In: Sex Roles, 47(9/10): 465-476.

Bayer, A. E. (1970): College and university faculty: A statistical description, ACE Research Reports 5(5). Washington, D.C.: American Council on Education.

Bayer, A. E./Astin, H. S. (1968): Sex differentials in academic rank and salary among science doctorates in teaching. In: Journal of Human Resources, 3(2): 191-200.

Bayer, A. E./Astin, H. S. (1975): Gender differentials in the academic reward structure. In: Science, 188: 796-802.

Bellas, M. L./Toutkoushian, R. K. (1999): Faculty time allocations nd research productivity: Gender, race, and family effects. In: Review of Higher Education, 22(4): 367-390.

Benjamin, E. (1999): Disparities in the salaries and appointments of academic women and men. In: Academe, 85(1): 60-62.

Bentley, R. J./Blackburn, R. T. (1990): Changes in academic research performance over time: A study of institutional accumulative advantage. In: Research in Higher Education, 31(4): 327-345.

Bentley, R. J./Blackburn, R. T. (1992): Two decades of gains for female faculty? In: Teachers College Record, 93(4): 697-709.

Bland, C. J./Center, B. A./Finstad, D. A./Risbey, K. R./Staples, J. (2006): The impact of appointment type on the productivity and commitment of full-time faculty in research and doctoral institutions. In: Journal of Higher Education, 77(1): 89-123.

Bradburn, E.M./Sikora, A.C./Zimbler, L.J. (2002): Gender and Racial/Ethnic Differences in Salary and Other Characteristics of Postsecondary Faculty: Fall 1998. Washington, DC: U.S. Department of Education, Office of Educational Research and Improvement (NCES-2002-170).

Braxton, J./Bayer, A. E. (1986): Assessing Faculty Scholarly Performance: Measuring Faculty Research Performance. San Francisco: Jossey-Bass.

Cole, J. R. (1979): Fair Science: Women in the Scientific Community. New York, NY: Free Press.

Cole, J. R./Zuckerman, H. (1984): The productivity puzzle: Persistence and change in patterns of publication of men and women scientists. In: M. W. Steinkamp/M. L. Maehr (Eds.): Advances in Motivation and Achievement: Vol. 2. Women in Science. Greenwich, CT: JAI Press: 217-258.

Creamer, E. G. (1998): Assessing faculty publication productivity: Issues of equity. In: ASHE-ERIC Higher Education Report 26(2). Washington, D. C.: The George Washington University Graduate School of Education and Human Development.

Dey, E. L./Milem, J. F./Berger, J. B. (1997): Changing patterns of publication productivity: Accumulative advantage or institutional isomorphism? In: Sociology of Education, 70 (4): 308-323.

Fairweather, J. S. (1993): Faculty reward structures: Toward institutional and professional homogenization. In: Research in Higher Education, 34(5): 603-623.

Ferber, M.A. (1986): Citations: Are they an objective measure of scholarly merit? In: Signs, Journal of Women in Culture and Society, 11(2): 381-389. 
Ferber, M. A./Green, C. A. (1982): Traditional or reverse sex discrimination? A case study of a large public university. In: Industrial and Labor Relations Review, 35(4): 550-564.

Ferber, M. A./Hoffman, E. P. (1997): Are academic couples at a disadvantage?, In M. A.Ferber/J. W. Loeb (Eds.): Academic Couples: Problems and Promises. Urbana, IL: University of Illinois Press: 182-207.

Gifford, A. (1980): Affirmative action impact on sex and race differentials in faculty salaries. In: Economic Forum, 11 (Summer): 107-116.

Ginther, D. K./Hayes, K. J. (2003): Gender differences in salary and promotion for faculty in the humanities 1977-1975. In: Journal of Human Resources, 38(1): 34-73.

Gordon, N./Morton, T./Braden, I. (1974): Faculty salaries: Is there discrimination by sex, race, and discipline? In: American Economic Review, 64(3): 419-427.

Hargens, L. L./Long, J. S. (2002): Demographic intertia and women's representation among faculty in higher education. In: Journal of Higher Education, 73(4): 494-517.

Harper, E. P./Baldwin, R. G./Gansneder, B. G./Chronister, J. L. (2001): Full-time women faculty off the tenure track: profile and practice. In: Review of Higher Education 24(3): 237-257.

Hoffman, E. (1976): Faculty salaries: Is there discrimination by sex, race, and discipline? Addition evidence. In: American Economic Review, 66(1): 196-198.

Katz, D. (1973): Faculty salaries, promotions, and productivity at a large university. In: American Economic Review, 63(3): 469-477.

Keller-Wolff, C. M. (2003): Moving forward or standing still? Progress in achieving wage equity for women faculty in the 1990s (Doctoral dissertation, University of Kansas). Dissertation Abstracts International, DAI-A 64/09, p. 3214, Mar 2004.

Koch, J./Chizmar, J. (1976): Sex discrimination and affirmative action in faculty salaries. In: Economic Inquiry, 14 (1): 16-24.

Loeb, J. W./Ferber, M. A. (1971): Sex as predictive of salary and status on a university faculty. In: Journal of Educational Measurement, 8(4): 235-244.

Loeb, J. W./Ferber, M. A. (1973): Representation, performance and status of women on the faculty at the Urbana-Champaign campus of the University of Illinois. In: A. S. Rossi/A Calderwood (Eds.): Academic Women on the Move. New York, NY: Russell Sage Foundation: 439-455.

Loeb, J. W./Ferber, M. A./Lowry, H. (1978): The effectiveness of affirmative action for women. In: The Journal of Higher Education, 49(3): 218-230.

Long, J. S. (1992): Measures of sex differences in scientific productivity. In: Social Forces, 71: 159-178.

Long, J. S. (Ed.). (2001): From scarcity to visibility: Gender differences in the careers of doctoral scientists and engineers. Washington, DC: National Academy Press.

Long, J. S./Allison, P./McGinnis, R. (1993): Rank advancement in academic careers: Sex differences and the effect of productivity. In: American Sociological Review, 58(5): 703-722.

Long, J. S./McGinnis, R. (1981): Organizational context and scientific productivity. In: American Sociological Review, 46, 422-442.

Martin, M./Williams, J. (1979): Effects of statewide salary equity provisions on institutional salary policies: A regression analysis. In: T. Pezzullo/B. Brittingham (Eds.): Salary Equity. Lexington, MA: Heath.

National Center for Education Statistics (2000): Digest of Education Statustics, 1999. Washington, D. C.: GPO.

National Center for Education Statistics (2003): Digest of Education Statistics 2002. Washington, D. C.: GPO.

National Center for Education Statistics (2005): Digest of Education Statistics 2004. Washington, D.C.: GPO.

Nettles, J. T./Perna, L. W./Bradburn, E. M. (2000): Salary, Promotion, and Tenure Status of Minority and Women Faculty in U.S. Colleges and Universities. Washington, DC: U.S. Department of Education, Office of Educational Research and Improvement. (NCES 2000-173).

Perna, L.W. (2001a): Sex differences in faculty salaries: A cohort analysis. In: Review of Higher Education, 24(3): 283-307. 
Perna, L. W. (2001b): Sex and race differences in faculty tenure and promotion. In: Research in Higher Education, 42(5): 541-567.

Perna, L. W. (2005a): Sex differences in faculty tenure and promotion: The contribution of family ties. In: Research in Higher Education, 46(3): 277-307.

Perna, L. W. (2005b): The relationship between family and employment outcomes. In: New Directions for Higher Education, 130: 5-23.

Persell, C. H. (1983): Gender, rewards, and research in education. In: Psychology of Women Quarterly, 8(1): 33-47.

Ransom, M./Megdal, S. (1993): Sex differences in the academic labor market in the affirmative action era. In: Economics of Education Review, 12(1): 21-43.

Sandler, B. (1973): A little help from our government: WEAL and contract compliance. In: A. S. Rossi/A Calderwood (Eds.): Academic Women on the Move. New York, NY: Russell Sage Foundation: 439455.

Sax, L. J./Hagedorn, L. S./Arredondo, M./Dicrisi, F. A. (2002): Faculty research productivity: Exploring the role of gender and family-related factors. In: Research in Higher Education, 43(4): 423-446.

Smart, J. C. (1991): Gender equity in academic rank and salary. In: Review of Higher Education, 14(4): 511-525.

Sonnert, B./with the assistance of Holton, G. (1995): Gender Differences in Science Careers: The Project Access Study. New Brunswick, N.J.: Rutgers University Press.

Stack, S. (1994): The effects of gender on publishing: The case of sociology. In: Sociological Focus 27(1): 81-83.

Stack, S. (2002): Gender and scholarly productivity: The case of criminal justice. In: Journal of Criminal Justice 30(2): 175-182.

Stack, S. (2004): Gender, children and research productivity. In: Research in Higher Education, 45(8): 891-920.

Steinpreis, R. E./Anders, K. A.,/Ritzke, D. (1999): The impact of gender on the review of the curricula vitae of job applicants and tenure candidates: A national empirical study. In: Sex Roles, 41(7/8): 509-528.

Stephan, P. E./Kassis, M. M. (1997): The history of women and couples in academe. In: M. A. Ferber/J. W. Loeb (Eds.): Academic Couples: Problems and Promises (pp. 44-79). Urbana, IL: University of Illinois Press.

Stith-Willis, A. M. (1999): Analysis of the status of women faculty in the United States since the enactment of equality legislation in the 1970s: What do the numbers suggest? (Doctoral dissertation, Virginia Commonwealth University). Dissertation Abstracts International, DAI-A 60/12, p. 4602, Jun 2000.

Suitor, J. J./Mecom, D./Feld, I. S. (2001): Gender, household labor and scholarlyl productivity among university professors. In: Gender Issues, 19(4): 50-67.

Toutkoushian, R. K. (1998a): Sex matters less for younger faculty: Evidence of disaggregate pay disparities from the 1988 and 1993 NCES Surveys. In: Economics of Education Review, 17(1): 55-71.

Toutkoushian, R. K. (1998b): Racial and marital status differences in faculty pay. In: Journal of Higher Education, 69(5): 513-541.

Toutkoushian, R. K. (1999): The status of academic women in the 1990s: No longer outsiders, but not yet equals. In: The Quarterly Review of Economics and Finance, 39: 679-698.

Toutkoushian, R. K./Conley, V. M. (2005): Progress for women in academe, yet inequities persist: Evidence from NSOPF: 99. In: Research in Higher Education, 46(1): 1-28.

U. S. Department of Education, National Center for Education Statistics (2002a): Tenure Status of Postsecondary Instructional Faculty and Staff: 1992-1998, (NCES 2002-210), by Basmat Parsad and Denise Glover. Project Officer: Linda J. Zimbler. Washington, D. C.: GPO.

U. S. Department of Education, National Center for Education Statistics (2002b): The Gender and Racial/Ethnic Composition of Postsecondary Instructional Faculty and Staff, 1992-1998, (NCES 2002160), by Denise Glover and Basmat Parsad. Project Officer: Linda J. Zimbler. Washington, DC: GPO.

Wenneras, C./Wold, A. (1997, May 22): Nepotism and sexism in peer-review. In: Nature 386, 341-343.

Xie, Y/Shauman, K. A. (1998): Sex differences in research productivity: New evidence about an old puzzle. In: American Sociological Review, 63(1): 847-870. 